\title{
POSITIONING OF SATYR DRAMA AND CHARACTERIZATION IN THE CYCLOPS
}

\author{
George W.M. Harrison
}

The Cyclops is an extremely tricky play and must have been one of the greatest challenges in Euripides' career. It does not track its plot on some revelation or the moral (or other) progress of one or more of the characters. Polyphemos blind does not have some sudden insight nor does he regret any actions of his life nor does he feel compelled to sacrifice himself for the good of a state about which he cares deeply, like Oidipous. The blind Polyphemos recalls a prophecy and realizes its fulfillment; unlike Teireisias, he does not make a prophecy or interpret a prophecy or understand the ramifications of some unseen force on the state. His 'epiphany', if one can call it that, is entirely personal and, true to character, includes a sneer - about Odysseus' continuing travels. Polyphemos blind is no more or other than Polyphemos blind. 'The drama of the play is carried by intersecting registers, or sometimes non-intersecting registers, of language rather than by action. ${ }^{2}$ This is not to deny that there is action; rather, the action remains secondary. What characters say and how they say it is more important than what they do. Each role displays a wide range of emotions and different kinds of speech within which each persona yet stays true to his character.

The Cyclops thus is an actors' play, rather than one configured first and foremost for the audience. The tragic diction affords many challenges to actors but also opportunities to play with the conventions of that tragic stage; it is hard to believe that the cast did not approach their parts with great relish. Silenus, for example, comparable to someone with the 'dry heaves', opens the play 'drunk' on his memories in the face of enforced abstinence. His flaccid comic-sized phallus is held in his hands in line 2 when he notes that 'this skin was taut with youth' and elsewhere in the monologue is used as a spear on shoulder (5), a spear thrusting into the shield of Enkelados (7), a ship's rudder $(15,19)$, and a rake (29). ${ }^{3}$ Like prologues, such as Medea and Trojan Women, he complains of his predicament, but already 'feminized'4 (so Trojan Women) he does not have the standing or initiative to redress 
the wrongs he has suffered..$^{5}$ Like other feminine or feminized speakers of prologues, his suffering is not his fault, so much so that he wonders whether all his former exploits were some imagined dream. ${ }^{6}$ He has equally been the victim of Hera $(3,11)$ and Tyrrhenian pirates $(11-12)$, against whom even Dionysos could not stand, nor could proximity of the satyrs to Apollo at Delphi (so Màźas, 18, for Cape Maleas by metonymy for Delphi) give them shelter. Silenos' self-admitted relegation to menial work of cleaning house, or rather cave, and waiting table, prepare the audience for his eventual subservient role as Ganymede.

The stichomathy upon the arrival of Odysseus (96) begins with rudeness from Silenos in both his aside to the satyrs at 104 , and his jeering at Odysseus' presumed lack of seamanship, although the satyrs themselves fell foul of contrary winds (110), as Silenos himself concedes. The satyrs, bored by Odysseus' travelogue and Silenos' gestured tour (106-30), ${ }^{7}$ must wander off-stage since the plot requires that they not be present when Silenos discovers that Odysseus has wine (139) and bargains Polyphemos' possessions for wine for himself. Until then, Silenos has malicious sport of Odysseus using ambiguous language in reply to questions about what food is on the island and what the Cyclopes eat, perhaps to test the son of Sisyphos (104) at word games. 'No one ever came here who wasn't digested'

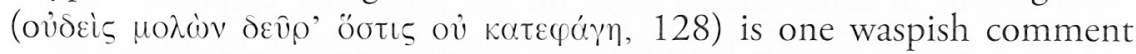
too far but is followed by Odysseus' ambiguous first plural in his indirect

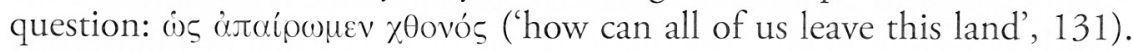
Silenos' answer in the next line, promising all co-operation, is probing, indicated by the cautious, postponed ¿̌v.

The discovery that Odysseus has wine, however, excites Silenos' mercantile instincts and cupidity. ${ }^{8}$ The characters speak at cross purposes, each fastened on what he wants and thus not comprehending the other with the inevitable frustration:? Silenos is concerned to distraction only with the wine and ignores resolutely Odysseus' requests and queries. Actors live for the chance to portray the range of emotions present in 140-50: the first half of 140 ( $\hat{\omega} \varphi \varphi^{\prime} \lambda \tau \alpha \tau^{\prime}$ cistóv) is spoken with wild enthusiasm but suspicion emerges in the second half of the line (ov oravísourv) which quotes Odysseus at $133 .{ }^{10}$ Odysseus' bragging reference to Maron, son of Dionysos, brings on Silenos' private reverie (142) of swaying Maron in his arms, outlasting an infant determined not to fall to sleep. Odysseus caustically misinterprets, to which Silenos (144) issues a challenge since he knows that he would recognize anything associated with Maron. When, however, wine is produced Silenos immediately forgets and muses that the wine he is about to swill need not touch his jaws, ${ }^{11}$ a line addressed either to himself or to the audience. The pun of Odysseus on 'flow', presuming 


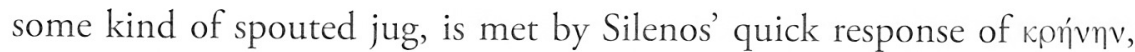
a spring coming from a rock (146), perpetually flowing, as any satyr might wish of wine.

These first smacks of wine fasten Silenos on its fragrance and bouquet, and draw out the language of a connoisseur in part to provoke Odysseus but also to prepare for later when Silenos tries to give Polyphemos a lesson

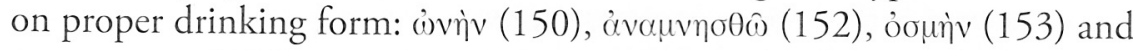
öøpaivoux (154) occur in rapid succession, and belong to the language of the aristocratic symposium, not a satyr desperate for drink. From this point on he becomes increasingly drunk with two immediate effects: sexual entendre in tandem with an incipient erection, ${ }^{12}$ and shorter, simpler words sometimes marking lack of comprehension. These are accompanied by a greater amount of alliteration, most pronounced at 163-203, hypermetric expressions (such as at 157), antilabes, that is a single line of verse with two different speakers, and an unusual internal rhyme at 203, all of which are textual indications that a drunk is more likely to break into the conversation and equally be interrupted. As the wine penetrates and a warm glow permeates, he apparently several times addresses the audience (163-74), ${ }^{13}$ and his speech becomes repetitive (262-9). He uses interjaculations more associated with comic diction, such as $\pi \alpha \pi$ atóg (153) and curses gently but amiably (ov $\left.\mu \dot{\alpha} \Delta \hat{\imath}^{\prime}, 154\right) .{ }^{14}$ The stichomathy ends at 162 when Silenus announces to the audience what animals and milk products he will gather for Odysseus (155-74). The drink has given him false courage: he snorts in hard gutturals what he would do to Polyphemos and his brothers, and holds in one hand his growing erection and makes a fondling gesture with the other. ${ }^{15}$ He then exits the stage briefly to collect sheep tethered together loaded with paniers, ${ }^{16}$ unless the satyrs bring the sheep and cheese, although it difficult to imagine how dramatically they would have known to do this. ${ }^{17}$

Silenos' exchange of wine for sheep and cheese is interrupted by the sudden appearance of Polyphemos. Silenos is commanding to the satyrs, ${ }^{18}$ wavering in grudging respect to Odysseus but towards Polyphemos he is instinctively officious and sedulous. Polyphemos' approach causes Silenos, unsuccessfully, to attempt to harness what little remains of his sobriety. ${ }^{19}$ He does not speak until Polyphemos looks directly at him and notices

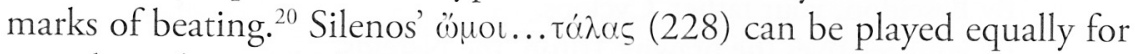
tragedy and comedy, but here the (in essence) throwaway line gives him a final moment to make a decision whether to protect Odysseus or protect himself by lying. The choice is not difficult. He is, however, not a talented liar. Logic begins to escape him as he invents the intentions of Odysseus and his crew. He starts with feigned horror, but quickly warms to his task 
(232-40):

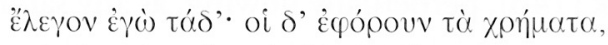

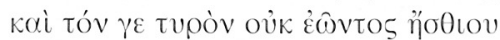

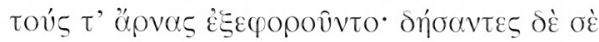

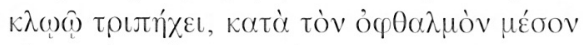

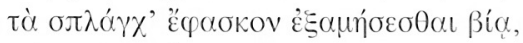

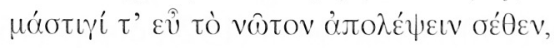

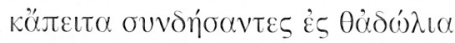

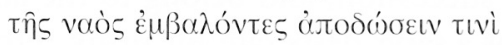

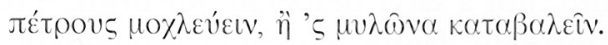

[240]

I told them this [that you were a god] but they took your stuff anyway... even though I didn't allow it... they have your cheese and your sheep. As for you... they intend to tie you up with foot and leg irons ten feet long.... and as to your eye....well... well.... and they said loudly they would pull your intestines out hand over hand, and crush your back with a whip and then chain you to the deck of the ship...they would sail off and sell you to someone to heave rocks or walk in a circle in a grain mill.

The frequent ellipsis and stream of non-sequiturs indicate that Silenos is making it up as he goes along, and one assumes that the visibly growing anger of Polyphemos spurs Silenos on to even greater fabrication. It is with relief that he suggests to Polyphemos at 250 that 'new tastes are

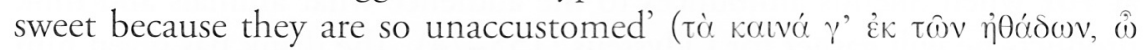

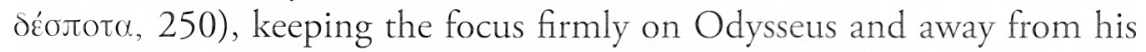
own duplicity. ${ }^{21}$

Odysseus' defense of his actions makes Silenos fearful once more, and so instinctively he 'prays' obsequiously (262-9): ${ }^{22}$

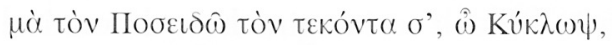

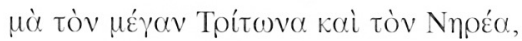

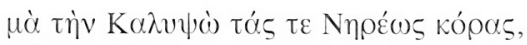

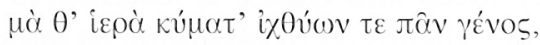

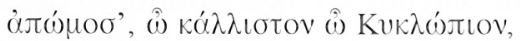

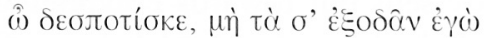

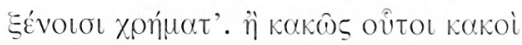

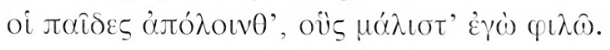

By Poseidon, your father, Cyclops,

By your relatives the brawny Triton, the Nereids,

By Calypso and the daughters of Nereus,

By all the waves which are holy, and all the species of fish,

I deny vigorously, most wonderful Cyclops,

greatest gentle master, that I sold your property at the road-side

to these foreigners for money. If I lie, may these my children

be put to death painfully. 
He does not, in fact, lie since he bartered the sheep and cheese for wine, not money, even if the chorus of satyrs on whose heads he has sworn is understandably terrified. Silenos is then quiet during the short exchange between Odysseus and Polyphemos and the epideictic speech of Odysseus (270-312). He reappears briefly only as transition between the two speeches of the agon, and is quiet again for Polyphemos' rebuttal (316-46), the prayer of Odysseus (347-55), the choral ode sung by the satyrs watching the killing, cooking, and consumption of two of Odysseus' crew (356-74), the 'threnody' of Odysseus upon prodding of the chorus (375-436), Odysseus and the chorus hatching the plan to blind Polyphemos (437-82), and the four-part choral ode (483-518), of which the inebriated Polyphemos sings the third section. He reappears only at 540, inserting himself in the stichomathy between Odysseus and Polyphemos that began at 519. He speaks only when asked a direct question by Polyphemos and, since Silenos' contribution is in aid of what Odysseus is trying to accomplish, it should be assumed that some stage action of Odysseus has drawn attention to Silenos; otherwise, there is little warrant for his sudden and unexpected participation.

What has Silenos been doing for 270 lines? Drinking. The ensuing scene requires that Silenos be totally drunk again, and staging would make it possible for Silenos to sit at one wing going through the wine and oblivious to all of the action at centre stage. ${ }^{23}$ At the end of the choral ode, Polyphemos indicated a desire to share the wine with his brothers, from which Odysseus is desperate to dissuade him. Polyphemos, drunkenly incoherent, helps by asking Silenos the wrong question - not 'should I go or stay?' but rather 'does it seem best to you to stay?' The question conditions the answer which would be Silenos' preference in any case: 'Why do we need others

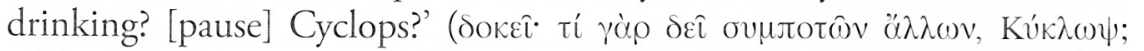
540). Polyphemos' non-answer extols the new green grass, which in all probability is the beaten earth in front of the cave, but it allows Silenos and Odysseus to sit Polyphemos down in one place and keep him there. Here begins the scene (542-89) of Silenos' wine theft, perhaps the best known in the play, and thus one not needing comment. It is stylistically comparable to the earlier one of Silenos becoming drunk: five instances of antilabes, gentle curses, hypermetric interjections, short words, slurred speech, and innocent merriment until all goes horribly wrong. 'Fruit of the vine' had long been an expression for 'wine', and Odysseus had just said that the vine was well known to his hand ( words can move conversations down unforeseen paths, and Polyphemos' mind takes Odysseus' words too literally, that is, physically, and notes of his own anatomy that 'the wood of the vine is wonderful' ( $\pi \alpha \pi \alpha \hat{\imath}$, oopóv $\gamma \varepsilon$

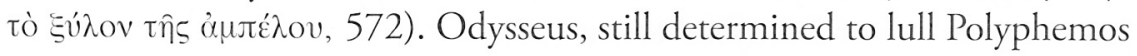


to sleep, suggests that 'drawing down' after a hearty meal brings on sleep, choosing oлx́w (573) which can be used both of sucking in wine and masturbation. Polyphemos, on his back gazing at the stars, dismisses constellations of the Graces, in favour of the Ganymede next to himself.

Too late the fat, balding, inebriated Silenos realizes that Polyphemos means him. One line (585) is spoken in alarm to Polyphemos, another (587) pleads for help from the satyrs, and the third, his last in the play (589), is addressed to anyone who will listen:

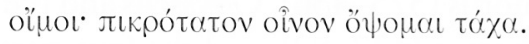

Oh! No!! I will soon see for myself the bitter aftertaste of wine.

This is a superb exit line for Silenos, dragged off into the cave. He has been a studied, but patinated and clouded, mirror of whomsoever he faced, and on the literal level the wine which was his heart's content is now also its undoing. Metaphorically, as Slenders points out in his contribution to this volume, 'bitter wine' can be taken to refer to oral sex, that is, Cyclops' emissions.

Odysseus presents a different challenge but one as delicious to whoever would portray the part. In his first appearance on stage he is not the vibrant, self-confident schemer of Homer $;{ }^{24}$ rather, he is tired, war-weary, and at this point wants nothing more than to survive. He refuses to rise to the

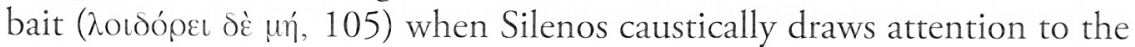
trickster Sisyphus, his putative forebear. He is old and broken, Troy no

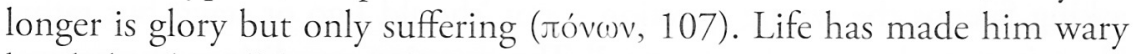
but behind it all he is still resourceful and therefore someone to whom others turn instinctively, as the satyrs do at 450, when Odysseus rejects simple murder as not having 'wit and sophistication'. Odysseus thus enters the stage at line 96, pompous yet cautious, practicing to himself what he would say to anyone he might meet:

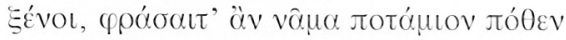
[96]

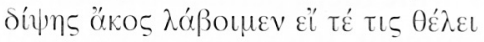

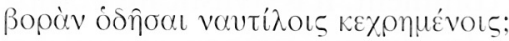
Friends, can you tell me where there is a place where one can get some water, and if there is someone who is willing to sell some meat to sailors who are without provisions?

The use of the optative with üv, the impersonal vocative $\xi \varepsilon \dot{v}$ or instead of pí $\lambda \tau \alpha \tau o l$, and the polite indefinite tıs make his entrance formal, but also inappropriate to the creatures he is about to encounter, as he himself realizes when sight of the satyrs informs him (incorrectly as it turns out) that he has come to one of Dionysos' towns (99). 
Odysseus' self-importance in announcing himself to Silenos as the 'King of the land of Cephalonia' is quickly deflated, and his diction changes several more times in their stichomathy (102-62). Initially Silenos asks all the questions but soon the tables are turned, once Odysseus has established that he is returning from Troy and off course. His questions about where he has landed are straightforward and direct, abandoning epic language. Even so, it takes him a while to put together the hints dropped by Silenos: ó $\chi 005$

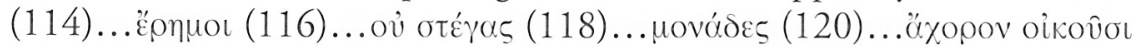
zóva (124). Only in response to a query about xenia does Silenos' 'they [the Cyclopes] say that foreigners bear the sweetest meat' ( $\gamma \lambda v \kappa v i \tau \alpha \tau \dot{\alpha}$ pa

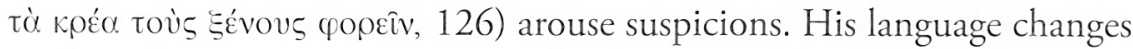

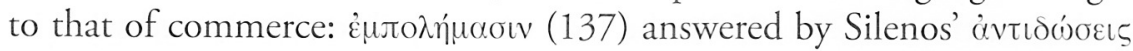
(138). Wine changes the situation once more and Odysseus instantly sizes up Silenos and realizes that he is in charge of the situation. In spite of being on an island with man-eating monsters, Odysseus' mastery is shown by the clipped phrases with assonance at 145 in which he taunts Silenos with an askos of wine. As Silenos craves more and more wine, Odysseus becomes more and more facetious, for example, offering him a cup (151) when Silenos would happily drink straight from the pitcher. The short phrases of Odysseus at 153 and 154 presume a stage action in which Odysseus teasingly keeps the wine back from Silenos. Гev̂oai vov (155), when he finally hands it over, is spoken with a wry smile and 157 is delivered in

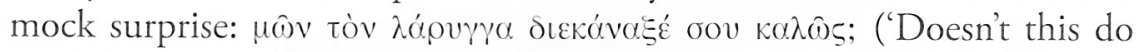
a good job of lubricating your larynx?')

Silenos then stumbles off stage and there follows the Helen-scene, which has troubled many commentators. ${ }^{25}$ It is merely a brief conversation (175-87) between Odysseus and the satyrs whose main purpose is to bridge the moment in which Silenos brings the sheep on stage which have been waiting in the wings. It also brings back epic reference, which looks forward immediately to the shock and horror of Odysseus when he must decide to face Polyphemos or hide (198-202):

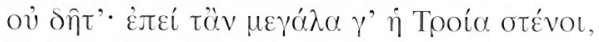

[198]

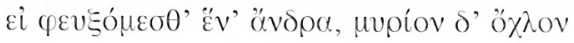

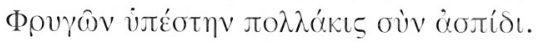

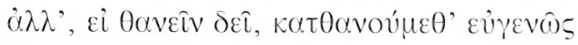

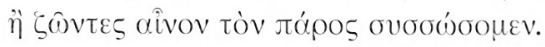

I can't do this again [i.e. hide as he did in the horse]. Troy would groan mightily if ever we ran away from one single man. I often with my shield held off thousands of Trojans. [to audience] If we have to die, we shall die nobly; if we live, we shall keep our reputation intact. ${ }^{26}$ 
Odysseus as recently as line 194 showed a proclivity to flight (

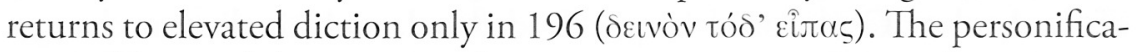

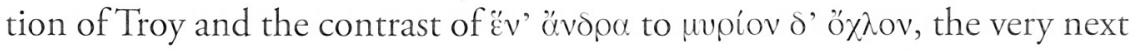
words in 199, signal this as one of the key moments in which Odysseus begins to recover his heroic stature.

Odysseus' attempts to win over Polyphemos are complicated not just by Silenos' contrary motives but by Polyphemos' first impression of them

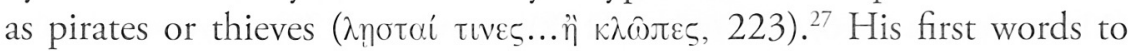
Polyphemos, seemingly reminiscent of the law courts, are weighed carefully.

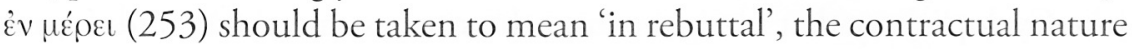
of the exchange is stressed with repeated use of $\pi(\omega \lambda \dot{\varepsilon}(\omega)$, ovitos for Silenos is demonstrative $(256,259)$, the lack of compulsion is stressed with its assumption of bona fides (Ékivv, 'willingly' 258), and the possessions of Polyphemos are referred to as a neuter collective ( $\tau \dot{\alpha}$ oó, 260).

A vocabulary familiar from the courts ${ }^{28}$ is joined to epic diction, such as $\hat{\omega} v \alpha \xi(290)$, and reference to specific places and shrines in Odysseus' set speech (285-312). ${ }^{29}$ Odysseus' claim that the Greek expedition against Troy saved shrines of Poseidon from pillaging by the Trojans is suspect. ${ }^{30}$ As a son of Poseidon, established by Silenos (262-9), Polyphemos would be under an obligation to Odysseus, or at the very least owe him xenia - that would at any rate be the aristocratic noblesse of the Homeric world. The speech sums up with a recounting of what has been suffered already (304-9):

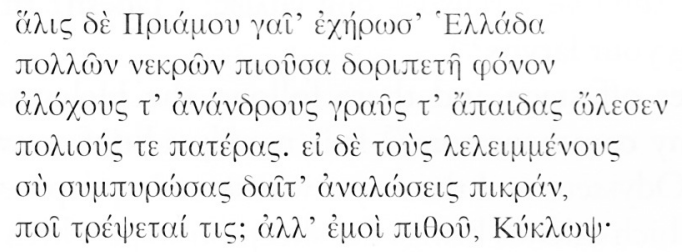

Priam's Troy has widowed Greece, drinking up dead gutted by the spear. Troy destroyed wives leaving them without spouses, and old women without grown sons. Troy destroyed gnarled fathers leaving them without children. If you grill the few who are left and squander them in a ghoulish banquet, where would someone turn for help? Let me win you over, Cyclops...

Polyphemos unfortunately was not given a hero's upbringing. ${ }^{31}$ Odysseus concludes the scene with a six-line prayer $(350-5),{ }^{32}$ half to Pallas Athena and half to Zeus, at the conclusion of which the chorus, peering into the cave, describe (356-74) in song the banquet of Polyphemos. ${ }^{33}$ The end of Odysseus' prayer with its vocative full of pain and rage, unwisely challenges Zeus' divinity: 'if you do not see what is going on here, Zeus, you should

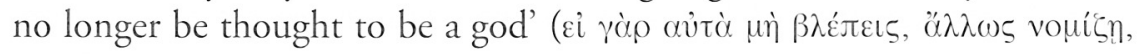




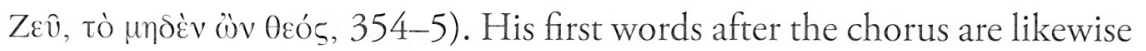
directed to Zeus, but events have suitably humbled him (375-6):

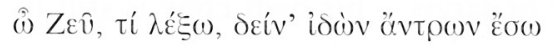

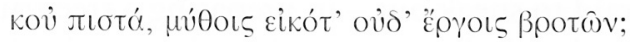

What, Zeus, can I say? Terrible things I saw in the cave,

hardly to be believed - you would think this myth, not acts of men.

Biehl breaks up this monologue (382-436) into four parts (382-95, 396-409, 409-22, 423-36) of thirteen lines each, and it does function in some ways like a threnody, although it clearly belongs to the tradition of the messenger speech. ${ }^{34}$ Odysseus moves from being shaken to unspeakable anguish. The speech is full of ellipses and pained rhetorical questions, particularly in the first two sections which relate the preparations for cooking and setting table by Polyphemos and then the slaughter of two of his crew men, for which Odysseus was compelled to act as steward. It was in this role ${ }^{35}$ that he has the sudden inspiration ( $\left.\tau \iota \varepsilon \varepsilon \hat{\imath} o v, 411\right)$ to give wine to Polyphemos, at which point he recovers his composure. Initially, it seems that the wine was just to get Polyphemos drunk to allow for escape but by the end of the third section (422-23) he is minded for revenge.

He does not enunciate a plan immediately, so the assumption must be that at this time he still does not have a plan. Between 423 and 450 he seeks the satyrs' assistance, promising them safety. Their initial response

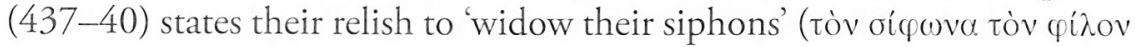

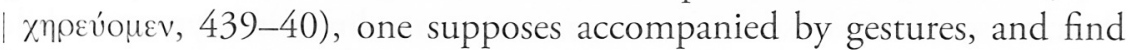

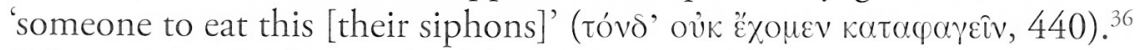
Odysseus ignores their reply, although he should have been able to guess on the basis of this alone that they would be useless, and again asks (441-2) if they would like to escape slavery. His tone is steady but concerned as he considers that Polyphemos would like to invite his two brothers to share wine and dance shoulder to shoulder with them. The satyrs advise that it would give Odysseus the chance to slit his throat when he straggled in the dance, or push him off a cliff, both of which are rejected by Odysseus. He enunciates his plan (451-63) with grammar that is disjointed because he is apparently thinking as he is talking and working out the details: the genitive kónov (451) starts the speech and brackets the accusative aùtòv with the demonstrative tov̂ $\delta$ ', followed by a participial phrase construing with is in the sense of 'how', itself having a participial phrase dependent

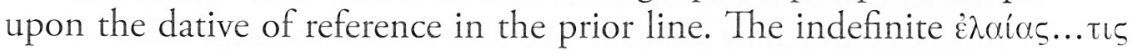
$(455)^{37}$ indicates that he is casting about for something suitable. The repeated ötav $(454,457)$ looks to be speech following a rest, and other expressions seem to mark a pause ( $\kappa_{i} \theta^{\prime}, 457$ and $i \delta \omega v(v, 458)$. It is from 
this moment that the Homeric hero re-emerges, fully in command of situation and language.

Confidently he directs his crew of satyrs - his own crew is still in the cave, either trapped or too afraid to sneak out - in preparing a tree trunk. Odysseus (476) tries to quiet the ebullient satyrs but their enthusiasm cannot be restrained and they break into song, which draws Polyphemos out of the cave. ${ }^{38}$ At 492 the chorus inserts Polyphemos into their dance line, coaxing him with $\varphi \varepsilon ́ \rho \varepsilon v v v$, and eleven lines later he takes over the tune as well, in perfect metre ${ }^{39}$ but far from perfect pitch. The main task of the actor portraying Odysseus at 519-89 is not to dissolve into laughter over the hijinks of Silenos and Polyphemos. Initially he is left trying to explain to a drunk that a goat-skin of wine is not a deboned deity but gives up and lets Polyphemos believe what he wishes so long as he keeps drinking himself to sleep. ${ }^{40}$ Odysseus taunts Polyphemos in his description since in his divinity Dionysos is everything that Polyphemos could never be. Unintentionally, but prophetically, Polyphemos says 'I am totally pissed. No one (oütı५) can

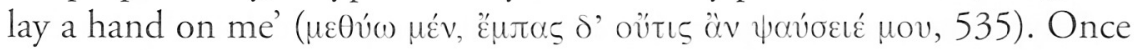
again Polyphemos asks the wrong question: he does not ask 'what is your name', but rather 'tell me a name, that by which it is necessary to call you'

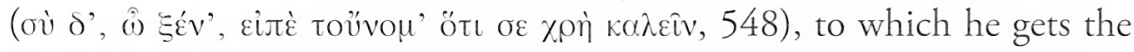
famous reply. The intervention by Silenos is equally infuriating to Odysseus and Polyphemos since both want Polyphemos to consume as much wine as possible, but Silenos' presence is necessary to get Polyphemos back into the cave so that Odysseus can return to commanding his satyr crew while his own crew still lurks in fear.

The total uselessness of the satyrs as sailors recalls Odysseus' crew to military discipline (650-1). Before then, Odysseus utters a second prayer (599-607) $)^{41}$ comparable to the earlier one to Pallas Athena and Zeus (347-55). A two-line curse invoking Hephaistos (599-600), fire god and fellow habitue of Sicily, is followed by a two-line invocation to Sleep (601-2). He concludes (603-7):

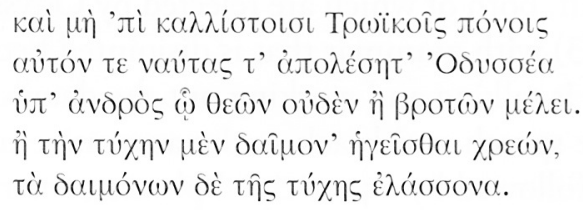

[603]

Do not let Odysseus and his sailors back from their most famous toils at Troy be destroyed by someone who does not acknowledge either gods or mortals. Otherwise, I shall be forced to believe in the divinity of Fortune and that the gods are less potent than random chance. 
Odysseus starts to fuss with the trunk during which once again the chorus

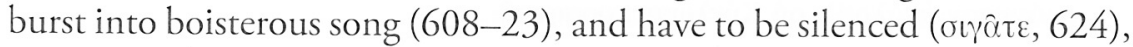
once again by Odysseus now clearly annoyed at them: the plural imperative is made emphatic by a seething pros theon, then by a vocative calling them wild animals, a second imperative, and instructions not to breathe, blink or even clear their throats. Feigned injuries (632-45) follow and Odysseus' consternation quickly spills over into exasperation. To give the satyrs something to do so that they do not get in the way, he directs through gritted teeth that they should chant their magical spell (652-3). To their great astonishment, the satyrs credit their charm with blinding Polyphemos and taunt him (663-89).

How does the Cyclops end? Roisman in this volume and in her book with Luschnig (2003) states the minority view that the Alcestis has an unhappy ending. Griffith, following Hall, is doubtless right in general: ${ }^{42}$

For the overriding message of the satyr play is that someone else (a hero, a god, a playwright) will adjust and redefine our (tragic) world for us - temporarily at least - into terms that guarantee absence of pain and toil. We are expected to collaborate in this process... The reward for our acquiescence will follow, in the shape of a miraculously happy ending.

But the extraordinary circumstances of $438 \mathrm{BC}$ and the countless unique features of the Alcestis ${ }^{43}$ do not allow us, I think, to judge that play according to the norms for the satyr play. ${ }^{44}$ As the final play, the one freshest in the minds of voters for the prize, a self-congratulatory ending that leaves one with a chuckle and a smile would have been most in the playwright's interests. For the year in which the Alcestis was produced, and the following one ${ }^{45}$ one should consider the possibility that there may have been over-riding concerns for Euripides.

Concomitantly, the natural way to view the Cyclops is that Odysseus takes Silenos and the satyrs off the island, partially since it would explain how satyrs can be with Dionysos in further adventures, although they could have escaped at another time in another way. At the end of his messenger speech (427-36), relating the deaths of two of his companions, Odysseus does seem to promise the satyrs that he will take them off the island:

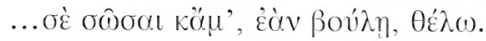

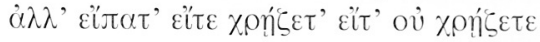

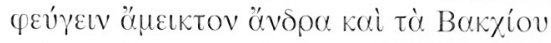

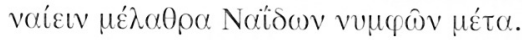

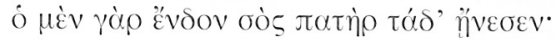

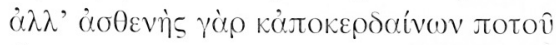

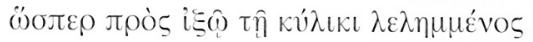

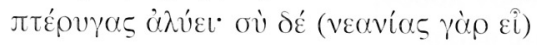




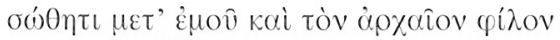

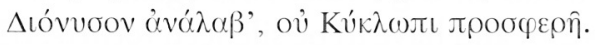

I want to save you and me, if you want this too. But tell me whether or not it is your desire to flee this uncivil man and sail to sites inhabited by Dionysos and his nymphs. Your father, he's inside, has agreed to this. He, however, is useless because he enjoyed too much wine. He doesn't know how to use his wings just as if stuck to the wine cup like flypaper. But you - you are after all young and strong - save yourselves along with me, return to Dionysos from this exile, your dear old friend, in no way resembling Cyclops.

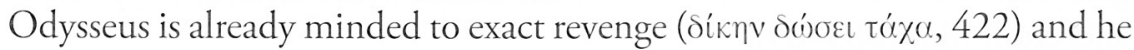
has already come to the conclusion that he needs assistance from the satyrs - there would be no other reason for stressing that Silenos, passed out in a drunken stupor, was useless, choosing carefully the alpha-privitive 'without strength' (do0عvìs, 432). The response of the satyrs thinks only of what they would like to do once off Sicily, so Odysseus' retort links escape with revenge, strongly implying his need of assistance from the satyrs (441-2):

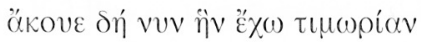

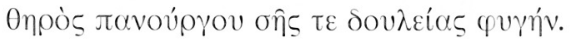

Listen then to what punishment I have in mind for that vicious animal and what escape from slavery I have in mind for you.

Eight of the twelve words in the two lines concern punishment, and only four address escape. In the following two lines (443-4) the satyrs finally fasten on the idea of revenge and the enjoyment they can take from it, but not yet the need of their help. With the exchanges at 465-72 the chorus embraces the plan (465) and offers to help (471). In between (466-8) Odysseus once more speaks of sailing away specifying the choregos, the rest of the satyrs, and Silenos, and at 472 again stresses his need of their help. There is an implicit contract.

This is a change from the beginning of the play. Discovering to his horror that the island is inhabited by man-eating monsters, Odysseus and Silenos have the following conversation (131-9):

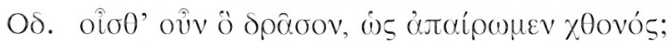

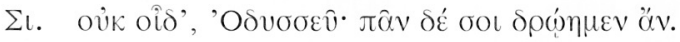

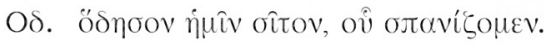

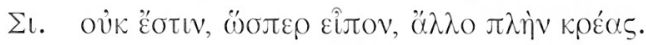

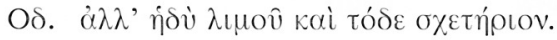

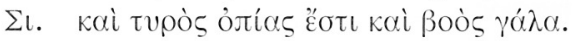

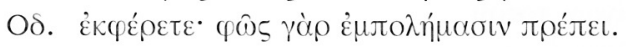

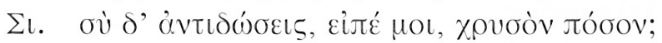

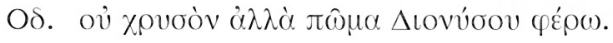


ODy. Do you know what you will do? How can all of us leave this land?

Sil. I don't know, Odysseus, but we will do everything we can for you.

ODy. Sell us the grain we need.

SiL. There isn't any, as I've told you, there is nothing except meat.

ODy. But meat is a sweet meal and suppressant for hunger.

SIL. There is also farmer's cheese and cow's milk.

ODy. Please, bring some. A man must see what he is to haggle over.

Sil. What do you have to trade, tell me, how much gold?

ODy. Not gold, but I have the currency of Dionysos.

131 and 132 each have two cola, the first in the singular referring to Silenos specifically, and the second half of both lines in the first plural. Odysseus is unintentionally ambiguous in who and how many is included in 'we', and Silenos, picking up on the plural but suspicious, inserts the dative of reference ool (132) in hopes that it will cause Odysseus to specify exactly who 'we' includes. Odysseus seems to be oblivious to the probing but nutiv (133), which can refer only to Odysseus and his crew, dashes Silenos' hopes

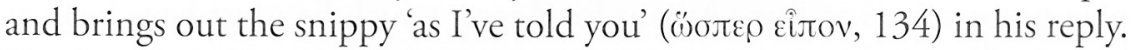
The last three lines in the citation emphasize commercial exchange and Silenos' resigned hopes. At no point in the play does Silenos think he has been offered an escape from the island.

Silenos does not have any assigned lines from 589 when he is dragged into the cave by Polyphemos, and Odysseus is silent from 653 until 689, at which point he speaks 6.5 of the final 21 lines of dialogue. From 663 to the end of the play the chorus speaking individually torment Polyphemos by skittering around the inside of the cave. Lunging in the direction of their taunts, Polyphemos repeatedly bangs his head on the walls of the cave. One way to stage the final scene of the play is to have satyrs exit the stage each one arm-in-arm with a sailor, and Odysseus propping up on his arm Silenos, too drunk to realize that he is being saved. ${ }^{46}$ The satyrs, however, have not fulfilled their contract, and another option is to have Odysseus and his sailors melt away while the satyrs provoke Polyphemos maliciously. Polyphemos demands several times that the satyrs tell him where the sailors are hiding in the cave. The sailors do not actually need to be there. Polyphemos is blind. He cannot check whether the satyrs are directing him towards empty space, or possibly towards satyrs - known for nimble athleticism - who leap away from the lunging Polyphemos while the crew escapes one by one. Having loaded his ship with the supplies that had thoughtfully been gathered but not unloaded, Odysseus returns for his obligatory exit lines. The ship sails while the satyr chorus crows, adding poignancy to the final two lines of the play:

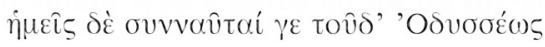

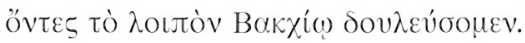


We are now crewmen of Odysseus;

For all the rest of time we will serve Dionysos

Through all this Silenos in the last 120 lines of the play is doing what he does best, what he did during lines 270 - 540, what he wanted to do more than anything else in the prologue: he is drinking. ${ }^{47}$ As in Poe's short story, 'Cask of Amontillado', his private audience with drink blinkers out anything and everything else.

$408 \mathrm{BC}^{48}$ like $438 \mathrm{BC}$, was a difficult year. The Spartan garrison at Decelea loomed over all Athens, including the Theater of Dionysos. By 408 it was clear that Athens was not to have a happy, miraculous ending and that citizens and leaders alike had let each other down. It is difficult not to see this play in light of the oligarchic coup of $411 \mathrm{BC}$ and the reaction after its fall. ${ }^{49}$ It is impossible to know whether the end of the play held out hope of some miraculous, happy ending for Athens or had a darker close. The former is more probable, but the latter is not inconsistent with Euripides' own preparations to leave Athens for Aegae, which he must have been at least mulling at this time.

Whether the Cyclops can be considered reflective, forward-looking, dark, or escapist depends in part on what one considers the norms of the genre. The most often cited passage is that of Demetrios On Style 169, quoted at the end of the introduction to this volume and considered by several of the papers in this collection. The larger context of $\$ 169$ gives some helpful guidance in how to approach and value the Cyclops. Demetrios is examining 'charm':

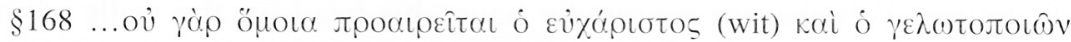

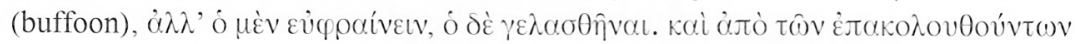

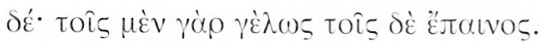

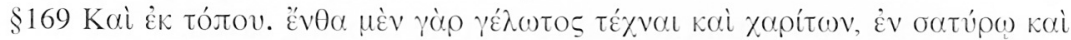

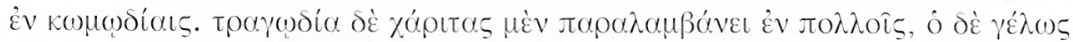

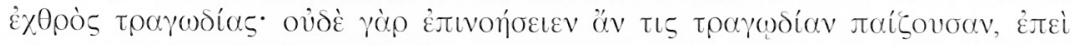

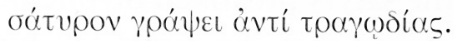

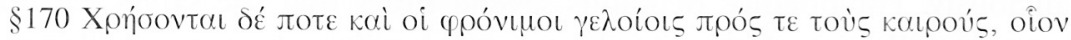

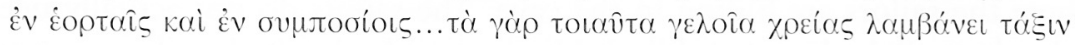
kai jvóuns.

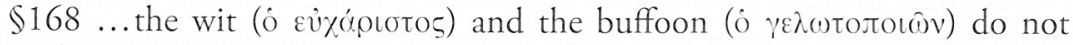
evoke the same reaction; rather, one shows sound judgement, the other provokes laughter. For that reason one is laughed at and the other praised. $\$ 169$ [Consider] also their [appropriate] place. The artistry of the clown and the savant are there in satyr drama and in comedy. Tragedy has charm ( $\chi \dot{\alpha}$ oıtas) in many places, but laughter is inimical to tragedy. No one would think to 'play at' tragedy, since [to do so] he writes a satyr drama instead of tragedy. 
$\$ 170$ Even somber souls sometimes tell jokes such as at festivals or at symposia... these kinds of light remarks have use as 'words to live by' and '[ethical] sayings'.

Griffith in this volume has made the case as compelling as it can be for satyr drama to be considered a sub species of tragedy, citing the evidence of Aristotle Poetics 1449 a19-23..$^{50}$ Demetrios has a different understanding, but one equally correct. It is impossible to know whether it is tied to a change in taste or the passage of time, but even Aristotle himself wrote the better part of a century after the first performance of the Cyclops and in a world far different from that of Euripides. Following Demetrios On Style 168, Odysseus is the evixóptotos and Silenos his foil and $\gamma \varepsilon \lambda \omega \tau$ (1)

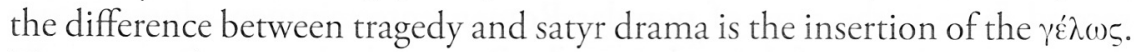
Their interplay, sometimes at cross-purposes, is what makes this play (and the genre of which it is the best representative) special and distinctive. The satyr drama must have jokes, and the Cyclops is full of them, some in the comic tradition and others along rather different lines, but amusing nonetheless. It is not a matter of interpretation or staging; it is a textual fact.

Griffith has noted that the modern instinct is to stage satyr drama as burlesque or farce. ${ }^{51}$ The genre had been moving in that direction for centuries. Demetrios' understanding of satyr drama already compares it more closely with comedy than tragedy. Horace (Ars Poetica 220-50) equated satire with satyr drama and considered it a middle genre between old and new comedy. ${ }^{52}$ Satyr drama was apparently written and performed in Rome during Horace's lifetime and so he should be an honest witness to how satyr drama was performed. ${ }^{53}$ Eustathius 1850.33 in his scholium to the Odyssey makes the statement that satyr drama is half-way between comedy and tragedy. ${ }^{54}$

How a play is written and how it is staged are, of course, two different things. Euripides had the advantage of being both playwright and director and so he was able to stage his vision. The subsequent history of satyrs is less certain. ${ }^{55}$ Terracottas may, or may not, indicate productions in the late classical and early Hellenistic periods on mainland Greece and the Peloponnese. Carpenter in this volume discusses the artistic evidence for non-Greek settlements in Magna Graecia down to c. 380 Bс. A satyr play was composed and performed for Alexander in India, ${ }^{56}$ but the restriction of satyr dramas from one per trilogy to one per festival must have greatly diminished their presence. The last attested name of a satyrographer to be preserved is Lucius Marius Antiochos of Corinth who won a prize at the Mouseia at Thespiae between 169 and 161 BC. ${ }^{57}$ His praenomen and nomen are Roman, his cognomen Anatolian Greek, and his place of residence Corinth, about twenty years before its destruction by Rome. In 
a sense his name and place alone suggest how satyr drama, even before the victory of Roman arms, became something much more than an Attic phenomenon tied to the festival cycle of one deity.

The history of performance during the Roman Empire is more problematic. Oxyrhynchos papyri indicate that satyr drama was at least being recopied into the middle of the second century $\mathrm{AD} .{ }^{58}$ Two forces may, however, have exerted a powerful influence on satyr drama. The first is the growth of private readings (recitationes) in camera in the homes of the wealthy. Nikolaidis, in an unpublished paper, put together an exhaustive list of types of literature in all genres for which there is evidence of recital; tragedy was not on the list, nor was there evidence of satyr drama. The second force is the taste of popular Roman entertainment. Just as satyr drama capped a set of three plays so the Romans had an exodium, usually an Atellan farce, after a drama. ${ }^{59}$ The Roman practice, parallel to the Greek, probably helped keep satyr drama in production, but if Senecan drama could not resist responding to the social influences of its time, ${ }^{60}$ satyr drama must have moved in the direction of Atellan farce, phlyakes, mime, pantomime, and perhaps even the mythological tableaux that were part of public executions. ${ }^{61}$ All of these are forms of entertainment unknown to Euripides at the time of composition but a significant part of the cultural climate in which later performances were staged. A performance of the Alcestis mentioned by Juvenal $(6.652-3)$ perhaps was meant to have a different message since the Roman audience pointedly included women; ${ }^{62}$ so, too, the Cyclops of Eumolpos in the Satyricon is in equal parts Homer, Euripides, and Petronius' own imagination. ${ }^{63}$

If Plutarch was only vaguely aware of satyr drama, he did not dismiss the possibility that satyrs once existed. In his Life of Numa 15 the early Roman king captures Picus and Faunus, creatures like satyrs, from whom he extorts prophecies and advice. Their capture resembles so closely the capture of Silenus that it is conceivable that Plutarch considered Faunus and Picus Roman equivalents of satyrs. In his Life of Sulla 27, soldiers of Sulla capture a satyr alive which pleased their commander, who looked forward greatly to interviewing such a creature and learning what he could from it. His delight soon turned to scorn as no matter what questions were put to the satyr, it only squeaked back disconsolately. In disgust, Sulla ordered it to be let go. Some satyr drama might also have seemed unintelligible, and out of favour with aristocratic taste, at least in one well defined venue. Satyr drama did not so much move in the direction of comedy as in the direction of Roman comic forms. I have argued elsewhere (2006) that it is not outside the realm of possibility that the same mythological material in a large center like Rome or Antioch or Alexandria could have received simultaneous 
exhibitions in different art forms, literary as well as visual, in which satyr drama could have found continued expression, even in circumstances of different reception. Satyrs and satyr drama both lived into the empire in reduced circumstances and both finally entered their twilight through lack of attention and the inability to appreciate them properly.

\section{Acknowledgements}

The author wishes to thank the participants in the conference for their conversation and ideas, many of which contribute to this article, the John Grissmer Grant in the Performing Arts which made it possible to do a new script for the modern stage, Anton Powell for his careful read of this article, and, as always, Jane Francis Harrison.

\section{Notes}

1 This insight is owed to L. Durrell, Pope Joan (106): 'Deprived of its idols and altars, Athens resembled nothing so much as a blind Polyphemos.' The frame of reference in his novella is Athens (and elsewhere) in the century after the separation of the Western and Eastern Christian churches, yet Durrell's implicit equation of 'idols and altars' as the 'eye-sight' of a city is provocative for his understanding of the Polyphemos myth.

${ }^{2}$ In a throwback to an Elizabethan-style frontispiece, the translation by George W.M. Harrison for the Xavier performance (2003) continued below the title line: being a study of the use and abuse of language and the tunnel vision of nonintersecting duplicities of men without women'. Unless otherwise specified, the translations in this paper are from the script for the Xavier performance; some of the character interpretations are also based on notes to the script.

${ }^{3}$ Carpenter and Griffith, both in this volume, are obviously correct that the chorus has 'satyr shorts' with a small-sized penis. In vase painting, however, Silenos is usually distinguished from the younger satyrs by grey hair and a long, drooping penis. It is hard to believe that the word for spear could occur four times in the monologue $(5,7,14,19)$ without some physical motion, particularly since it is each time the last word in the line.

${ }^{4}$ For feminization of male characters in drama, see Fletcher in this volume; Griffith in this volume, following Hall, would see recapturing masculinity as key to the shared cultural content of the play.

5 róvovs is almost the first word he utters. It compares well with Odysseus who

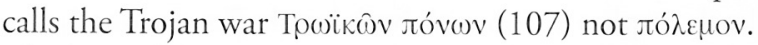

${ }^{6}$ Line 8 ('do I massage an imagined dream') purposefully evokes Calderon's, $\mathrm{La}$ vida es sueño, in that the mention of a dream at the beginning of the play allows for the play to be staged as a dream sequence, or for the audience to interpret it as such. Although clearly not Euripides' initial intention, the director of the Xavier production staged it in this way, and G.W.M. Harrison's 'Maron's Wine', a two-act 


\section{George W.M. Harrison}

play of which the Cyclops is the second act, sets the first act in a restaurant so that the second act is a reminiscence.

Reminiscing, such as Hecuba does in Trojan Women, is also a standard feature in prologues spoken by a character who has lost everything, that is, one who is either feminine or feminised. The beginning of such plays makes clear that characters like these have only their past; the future does not hold any prospects.

7 oủdeis ('no one') is first uttered by Silenos, not Odysseus, in a pun unintended

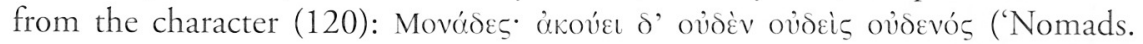
No one hears nothing of nobody'). No-mads, accepting the variant reading of L (vouádes), made a pun on Polyphemos who spends the entire play angry at someone or something.

8 The text again makes this clear since the preferred word in the play for 'sell' is not $\pi \omega \lambda \dot{\varepsilon} \omega$ but ö $\delta$ qov (133), a pun on the name of Odysseus.

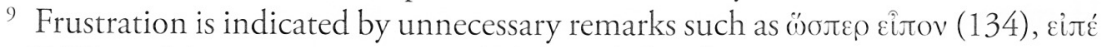

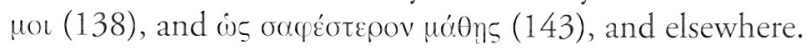

${ }^{10}$ If Silenos had not cited Odysseus' own words, it would be easy to take the sentiment ('we have been out of that for the longest time') as genuine, but quotation in repartee more often than not is sarcastic.

${ }^{11}$ Translation of line 146 in the Xavier script as 'this need not touch the walls of my cheeks' is clearly wrong since the $\gamma$ vátoov of Polyphemos will have a very difference experience, which seems to be the implied contrast here. The literary reminiscence is to Martial 7.20 where the bucca, or 'insides of the cheeks', is a reference to homoerotic foreplay, something Silenus is fated to suffer in the play.

${ }^{12}$ The Xavier script clearly understands Polyphemos' 'Then there is this bald old man, whose face is swollen and blotchy from being beat' (

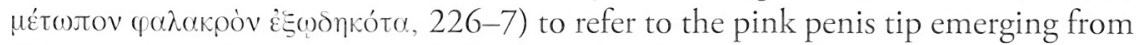
lighter coloured uncircumcised foreskin; drunkenness and sexual excitement are hardly without parallel.

13 Silenos had already conflated the audience with the chorus at the end of the prologue. As he becomes more and more drunk, he is less able to distinguish between the ephebes on stage in satyr shorts and masks and members of the audience, who during the performance of the fourth play would presumably have had food and wine themselves. The more curtailed costume of a satyr chorus, which also depicted roles closer in age to the members of that chorus, would have made identification between actor and role, and hence actor and audience, more fluid than in (e.g.) tragedies where the chorus would have depicted old men or old women and worn head-to-toe garments.

${ }^{14}$ Parodied later by Polyphemos when drunk, he comes to identify himself with Dios/Zeus.

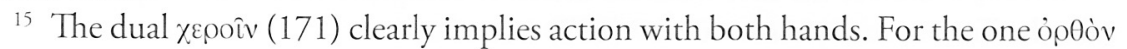
¿̇گavıotóval (to stand up straight, 169) implies something physical as well as meta-

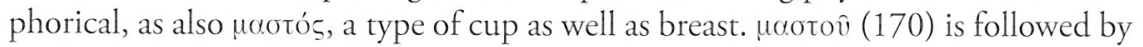

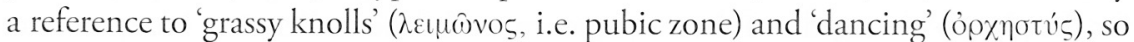
one should infer that while he is fondling a nipple-bottomed cup (physical object), his mind dreams of female anatomy. A drinking vessel shaped like female anatomy 
has its parallel in an Attic scyphos in the Ashmoleon (acq. 1974.344; sixth/fifth century) whose tripod base is a penis plus two testicles.

Silenus openly states his intention to hide the wine from Cyclops; whether he also would keep it from the other satyrs is less certain but seems indicated by their apparent ignorance of the wine when talking to Odysseus and their later deep annoyance with Silenos.

${ }^{16}$ Sheep (and goats) can bear loads - they just cannot carry as much as mules and donkeys. Bringing sheep on stage in ancient, and modern, productions of the Cyclops is difficult. They were not allowed in Seaford's Magdalen (Oxford) production. The Xavier production was to have had four sheep per performance, but the rental cost of $\$ 400$ per sheep per performance was prohibitive for a four-day run. Dogs wearing flokatis were suggested, but the idea was mercifully discarded.

${ }_{17}$ Choral exits and entrances in three-act tragedies are of little value in analyzing the one-act single-scene satyr drama.

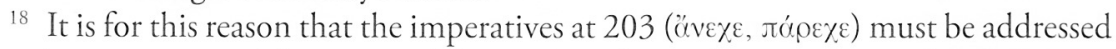
to the satyrs not Odysseus and his crew. Silenos does not care if Odysseus is destroyed - it actually solves the problem for him...so long as he can hang on to the wine. It makes more sense to have Silenos speak these words, encouraging the satyrs to scatter before Polyphemos comes on stage and they are interrupted by him, following the manuscript tradition accepted by Biehl in the Teubner. Tyrwhitt's emendation, followed by Diggle in the OCT, assigned the words to Polyphemos and makes them an expression of Polyphemos' annoyance at the nervous scampering of the satyrs fearful of him.

19 This would explain why there are twenty-five lines of dialogue between Polyphemos and the chorus before Silenus speaks. A comic character, like Pseudolus, would have spoken immediately and tried to misdirect the situation. One interpretation of the silence of Silenos is that he is slapping his face (or similar mute action) trying to force sobriety.

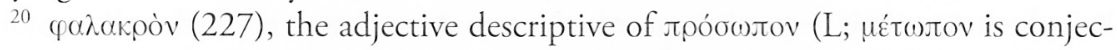
tured by Tyrwhitt and accepted by Diggle as lectio difficilior), has been taken by Slenders in this volume, and others, as presuming that the 'face' represents the glans peeking out of his erect phallus. Equally, if Silenos has been bruising/abusing himself, he could appear 'blotchy'. It is easy to believe that both could be true, given other instances of double entendre by Silenos.

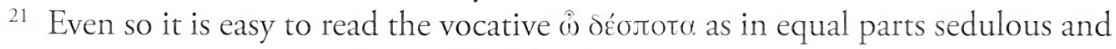
scorn, not uncommon in the world of slaves to masters.

${ }^{22}$ For these lines as a prayer see Fletcher in this volume. Silenos is trying so hard to avoid blame that he calls on the Nereids twice.

${ }^{23}$ Odysseus in the fourth part of his messenger speech tells the satyrs that their father is inside the cave incapacitated by drink (432). The staging implied by this remark would seem to be that Silenos was sitting off to the side silently drinking, and followed Odysseus into the cave when Odysseus brought in wine for Polyphemos.

${ }^{24}$ If comparisons are made with the Polyphemos scene in the Odyssey, contrasts with the Odysseus at the court of Alcinoüs are as informative. 


\section{George W.M. Harrison}

${ }^{25}$ Ambrose and Slenders in this volume tussle with the level of language and coarseness intended, a problem equally vexing for translators and interpreters. Shelley, for example, calls her a 'wanton wretch', the Vermont translation of Ambrose's seminar a 'traitress', and the Xavier script a 'prime piece of ass'. Shelley assigns these lines to Silenos which dramatically is impossible. The language of the satyrs, probing whether Odysseus and his crew took turns raping Helen, is consistent with their sexual drive throughout the play, as is clear already from their parodos and their 'athletic antics' decried by Polyphemos at his entrance (203). Commentators troubled by the passage overlook that the view of Helen in the Cyclops is consistent with Euripides' over-all assessment, and this passage is also consistent with the post-Homeric tradition in which Menelaos had promised to kill Helen or hand her over, to which allusions are made in Euripides' Helen and Trojan Women; cf. Michelini (1987). Talk of Helen is somewhat gratuitous since the prize awarded Odysseus was Hecuba; Helen would not have been in his possession, or that of his sailors, at any moment.

${ }^{26}$ It is hard to believe that the last two lines are not delivered to the audience and do not refer to the current dire political and military situation.

${ }^{27}$ Odysseus claims to be a Cretan pirate in the Odyssey so Polyphemos' presump-

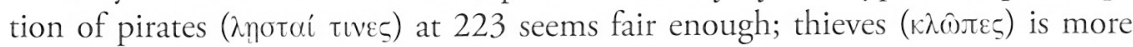
interesting because of the obvious pun on Kyklopes.

${ }^{28}$ So, especially, the perplexing reference to incarceration with censure over

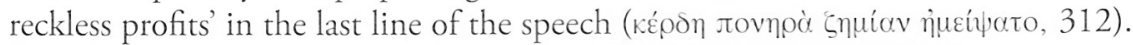
Trial and conviction are outside the realm of what could possibly have happened to the nomad Polyphemos.

${ }^{29}$ As interesting is the proliferation of 'p' sounds and appearance of a-privitives.

${ }^{30}$ One suspects, once again, that the rhetoric is more for the contemporary audience.

${ }^{31}$ Marshall and O'Sullivan admirably cover the speeches of Odysseus and Polyphemos in their respective contributions to this volume; no further discussion thus is needed here.

32 For which see Fletcher in this volume. In the three lines before the prayer, Odysseus once again characterizes the Trojan War as jóvovs.

33 There is no room here for an analysis of the ode (356-74) but its imperatives and other features seek close comparison with the magic spell chanted by the chorus (656-62). The chorus (361) asks not to be consumed by the Cyclops as they also had when they fed him at his entry. At least one line in the ode is missing and several lines are interpolated making it risky to draw any inferences.

${ }^{34}$ Acknowledged by Biehl (50) in his conspectus metrorum: aggelia sive narratio Ulixis.

35 Parallelism to Silenos as waiter (29-31) would imply (extrapolating from Fletcher in this volume) that Odysseus must be 'feminised' here in order to make recovery of his masculinity imperative.

36 The text at $439-40$ is so mutilated that Diggle in his apparatus writes 'de seqq. despero'. The general sense is clear, however, in spite of copyists' either not understanding the sexual implication, or perhaps worse, understanding without 
sympathy.

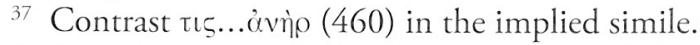

38 Lines 511-12, sung by the chorus, would seem to indicate that the terrified crew of Odysseus emerge from the cave at this point.

39) Metrical analysis by Biehl 50-1.

40 I suspect this part of the plot was not so improbable to pre-20th century audiences where drunkenness was the anaesthetic available to surgery and dentistry.

41 Cf. Fletcher in this volume.

42 Griffith 2002, 234-5, Hall 1998; cf. also Slater n. 49 in this volume. 'Pain and toil' in the quote from Griffith is, of course, Greek róvos, the most frequent word spoken by Silenos and Odysseus in the Cyclops.

43 See Slater and Roisman in this volume but, esp., Marshall 2000 and 2004.

44 The standard features of a satyr drama are set out by Ambrose in this volume.

45 See Storey in this volume.

46 For the Xavier production the director chose to have Odysseus hold Silenos in a way visually reminiscent of the vase on which the disgusted Herakles props up the drunken Hephaistos. This vase was known to the director, and his chorus leaving linked arm-in-arm was, again purposely, reminiscent of the exodus of Aristophanes' Lysistrata. For the Xavier production the reminiscence was stronger than perhaps in other productions of the Cyclops since the satyr chorus was played by women.

47 A considerable number of late classical terracottas of the drunken Silenos have survived, from Tanagra, some of which were exhibited at the Musée des Beaux Arts, part of a traveling exhibition from the Louvre. Others are also on display in the museum at Olympia, and it is not out of the realm of possibility that one or more might have been inspired by Euripides' play.

48 For the date of the play, see Marshall 2001.

49 Comparisons with the theater and movies during and after the junta of the Greek colonels (1967-1974) come easily to mind; cf., esp., Gonda van Steen (2000) 178-80, Garland (2003) and Hall's essay in Hall (2004).

50 On a broader understanding, the main differences between tragedy and comedy are metrical and status of character portrayed (mythological aristocrats vs. humans). In both these crucial distinctions satyr drama adheres to tragic practices. An argument, ultimately unconvincing, has recently been made that tragedy itself was importing some comic conventions; see Kirkpatrick and Dunn 2003.

51 Taplin and Wrigley of the Archive of Performance of Greek and Roman Drama report 32 productions of the Cyclops between 1882 and 2003. Of these 16 were definitely school productions and only 7 professional productions, one of which was the famous puppet theater by Arnott (1974). Of the remaining 9, one was done as a musical (1983) and so is more probably a professional company. Roberto Ciulli staged the Cyclops four times between 1978 and 1982 in Germany. The National Theater of Greece staged productions in 1936, 1959, and 1974 (all significantly at times of political turmoil or just after suppression of a coup).

52 So Plotnik 1979, 329-35.

53 Wiseman 1988, 1-13. 
54 Quoted by Biehl p. 2. Biehl himself (vi-vii) lists with examples twelve types of comic diction found in the Cyclops.

55 In what follows I leave off any discussion of Marsyas, for which see Lasserre 1973.

56 Storey in this volume.

57 Podlecki in this volume n. 1.

58 Griffith in this volume n. 20.

59 Sutton 1979, 53.

60 Harrison 2000 and 2005.

61 The plots of some of these executions, so Martial Liber de spectaculis, are also ones known from satyr drama; cf. Podlecki in this volume. See also Coleman 1990.

62 Marshall 2004, 38.

63 Ferri 1988, 313-15. 